\title{
Preliminary report on yield productivity and mineral composition of the fig tree as a function of boron and cattle manure fertilization in Brazil
}

Luiz Carlos Santos Caetano ${ }^{a *}$, Almy Junior Cordeiro de Carvalho ${ }^{b}$, Janie Mendes Jasmim ${ }^{b}$

a INCAPER, Rua Dom Fernando, 39, Independência, 29306-350, Cachoeiro de Itapemirim, ES, Brazil

luizcaetano@incaper.es.gov.br

b UENF, Avenida Alberto Lamego, 2000, 28015-620, Campos dos Goytacazes, RJ, Brazil

${ }^{*}$ Correspondence and reprints

Fruits, 2006, vol. 61, p. 341-349 (C) 2006 Cirad/EDP Sciences All rights reserved DOI: $10.1051 /$ fruits:2006033 www.edpsciences.org/fruits

RESUMEN ESPAÑOL, p. 349
Preliminary report on yield productivity and mineral composition of the fig tree as a function of boron and cattle manure fertilization in Brazil.

Abstract - Introduction. Information correlating leaf nutrient contents to fig tree yield is still rare in Brazil. The objective of our research was to evaluate the effect of fertilization with boron and cattle manure on fig tree productivity and the leaf and fruit nutrient contents, and to estimate the extraction of nutrients by the crop. Materials and methods. The treatments consisted of five boric acid levels $[(0,20,40,60$ and 100) g per plant $]$ combined with two levels of cattle manure [(0 and 10) kg per plant]. The experimental design was in randomized blocks in a split-plot scheme with four replicates. The cattle manure levels constituted the plots, and the boron levels the subplots. We studied tree productivity, macronutrient and micronutrient leaf and fruit contents, amounts of nutrients extracted per ha and per crop yield, and fig tree leaf and fruit dry matter nutrient contents as a function of sampling dates. Results. Fruit yield productivity, average fruit weight and number of fruits per tree were not affected by B fertilization but they were by cattle manure levels, which increased the fig tree productivity. The macronutrient and micronutrient leaf and fruit contents obtained are discussed in relation to Brazilian results already published. The levels of cattle manure did not significantly affect the amount of nutrients extracted from green fig yield. The $\mathrm{Mn}, \mathrm{Zn}$ and $\mathrm{B}$ leaf contents and the fruit extraction of $\mathrm{Mn}$ and $\mathrm{B}$ increased linearly with boric acid levels. The fig tree leaf nutrient contents varied with the plant physiological stages during its production cycle. Conclusion. These results should be taken into account for the development of fig tree fertilization programs in Brazil.

Brazil / Ficus carica / fertilizer application / boron / farmyard manure / mineral content / leaves / fruits / yield increases

Résultats préliminaires sur la productivité et la composition minérale du figuier en fonction de la fertilisation en bore et en fumier de bovins au Brésil.

Résumé - Introduction. Les informations sur le lien entre la teneur en éléments nutritifs des feuilles et la productivité du figuier manquent encore au Brésil. L'objectif de nos recherches a été d'évaluer l'effet de la fertilisation avec du bore et du fumier de bovins sur la productivité du figuier, la teneur en éléments nutritifs des feuilles et d'estimer l'exportation des éléments minéraux dans les fruits récoltés. Matériel et méthodes. Les traitements ont été constitués par cinq niveaux d'acide borique $[(0,20,40,60$ et 100$) \mathrm{g}$ par plant $]$ combinés à deux doses de fumier de bovins $[(0,10) \mathrm{kg}$ par plant]. Le dispositif expérimental a été celui de blocs randomisés selon un schéma de split-plot à quatre réplications. Les doses de fumier ont constitué les traitements et les niveaux de bore les sous-traitements. Nous avons étudié la productivité des arbres en fruits, la teneur des feuilles et des fruits en macro et microéléments, la quantité d'éléments minéraux extraite par ha et par récolte, la teneur minérale de la matière sèche des feuilles et des fruits en fonction des dates de prélèvement. Résultats. La productivité, le poids moyen des fruits et le nombre de fruits par arbre n'ont pas été affectés par la fertilisation en bore, mais ces paramètres ont varié avec les doses de fumier, qui ont amélioré le rendement du figuier. La teneur des feuilles et fruits en macro et micro éléments sont discutés par rapport aux résultats obtenus au Brésil déjà publiés. Les doses de fumier n'ont pas affecté de manière significative la quantité d'éléments extraits à partir de la récolte de figues vertes. Les teneurs des feuilles en Mn, Zn et B et l'extraction par le fruit du Mn et du B ont augmenté linéairement avec les différents niveaux d'acide borique. Le contenu en éléments minéraux des feuilles de figuier a varié avec le stade physiologique du plant au cours de son cycle de production. Conclusion. Il sera important de tenir compte de ces résultats pour le développement des futurs programmes de fertilisation du figuier au Brésil. Brésil / Ficus carica / fertilisation / bore / fumier / teneur en éléments minéraux / feuille / fruits / augmentation de rendement 


\section{Introduction}

Despite the classical papers of Pereira [1] and Quaggio et al. [2], information correlating leaf nutrient contents to fig tree yield productivity is still rare under Brazilian conditions. The chemical analysis of fruit at harvest gives a good indication of the amount of nutrients mobilized by the plant and the fruit yield and allows the estimation of the amount of nutrients exported by the harvest, which can be used as a reference for calculating fertilization needs [3].

Fertilization with cattle manure is widely recommended for fig tree crops. CampoDall'orto et al. [4] recommend the application of $10 \mathrm{~kg}$ of cattle manure per planting hole, at planting time, and an equivalent amount per plant every year. The increase in soil organic matter content causes, among other effects, an increase in soil $\mathrm{pH}$ and base saturation, as well as leading to the complexation and precipitation of aluminum from the soil solution [5, 6].

Boron is related to many of the plant physiological processes, which are affected by its deficiency, such as sugar transport, cell wall synthesis, lignin deposition, cell wall structure, carbohydrate, ARN, IAA, phenol and ascorbate metabolisms, and plasma membrane integrity [7]. In the fig tree, boron deficiency causes, among other symptoms, the death of apical buds and stem crack [1]. Boron leaf reference contents are between (30 and 75) $\mathrm{mg} \cdot \mathrm{kg}^{-1}$ under Brazilian environmental conditions [2], but they vary with the plant physiological stages during its production cycle.

The objective of our research was to evaluate the effect of fertilizing the fig tree with both boron and cattle manure on the plant yield productivity and on leaf and fruit macro- and micronutrient contents, and to estimate the crop yield nutrient extraction.

\section{Materials and methods}

The experiment was carried out between November 2003 and April 2004, on an experimental area in the Universidade Estadual do Norte Fluminense, Brazil (21 ${ }^{\circ}$
19' 23" S and 41 19' 40" W), in a dystrophic yellow latossol. The orchard was composed of 2-year-old fig trees of the cultivar Roxo de Valinhos conducted with twelve productive branches spaced $3 \mathrm{~m} \times 2 \mathrm{~m}$. Before setting up the experiment, $300 \mathrm{~g}$ of dolomitic limestone, $100 \mathrm{~g}$ of $\mathrm{P}_{2} \mathrm{O}_{5}$ and $10 \mathrm{~kg}$ of cattle manure per plant were applied and, throughout the experiment, each plant received, every 2 months, $20 \mathrm{~g}$ of $\mathrm{N}$ and $20 \mathrm{~g}$ of $\mathrm{K}_{2} \mathrm{O}$ per plant. Soil chemical and physical analyses (table I) were achieved with soil samples taken from the tree canopy shade area.

The experimental plots consisted of four trees in a line, of which the two central ones were used for analyses. The treatments consisted of five solid form boric acid levels [ $(0$, 20, 40, 60 and 100) g per plant] combined with two levels of cattle manure [ 0 and 10) $\mathrm{kg}$ of manure per plant]. The experimental design was in randomized blocks with four replicates in a split-plot scheme, in which the cattle manure levels were in the plots and the boron levels were in the subplots. When sampling times were considered, they were taken as the split-split plots in a split-plot scheme in time.

The boron levels were split into three applications: $1 / 4$ in December 2003, $1 / 2$ in January 2004 and 1/4 in February 2004. Addition of cattle manure was carried out in December 2003. Both cattle manure (table II) and boric acid were applied $40 \mathrm{~cm}$ from the tree stem (around the plant on the crown projection area). Dolomitic limestone at $1500 \mathrm{~kg} \cdot \mathrm{ha}^{-1}$ was applied on the surface of the experimental area. All plants also received additional irrigation (75\% of $\mathrm{ET}_{0}$ ) and nitrogen fertilization, providing $120 \mathrm{~kg} \cdot \mathrm{ha}^{-1}$ of $\mathrm{N}$ and $80 \mathrm{~kg} \cdot \mathrm{ha}^{-1}$ of $\mathrm{K}$. The plants were pulverized with mancozeb and azoxystrobin to control fig tree rust disease (Cerotelium fici). Green figs were harvested between January and April 2004.

To determine the nutrient contents in the leaf and fruit dry matter, samples were taken on 27 January and 10 March 2004, respectively, in the fruit yield period, at 130 days after pruning, and at the end of the fruit yield period, at 173 days after pruning. The most recent fully developed sun-exposed leaves, without petioles and not subjected to either 
Table I.

Characteristics of soil samples of the area in Brazil where experiments were carried out to study the effect of boron and cattle manure on fig tree productivity.

(a) Chemical analyses

\begin{tabular}{|c|c|c|c|c|c|c|c|c|c|c|c|c|c|c|c|c|c|c|c|c|}
\hline \multirow[t]{2}{*}{$\begin{array}{l}\text { Depth } \\
(\mathrm{cm})\end{array}$} & \multirow[t]{2}{*}{$\mathrm{pH}$} & \multirow[t]{2}{*}{$\begin{array}{c}P \\
\left(\mathrm{mg} \cdot \mathrm{dm}^{-3}\right)\end{array}$} & K & $\mathrm{Ca}$ & $\mathrm{Mg}$ & Al & $\mathrm{H}+\mathrm{Al}$ & $\mathrm{Na}$ & \multirow[t]{2}{*}{$\underset{\left(\mathrm{g} \cdot \mathrm{dm}^{-3}\right)}{\mathrm{C}}$} & $\begin{array}{l}\text { Sum } \\
\text { of bases }\end{array}$ & $\begin{array}{c}\text { CEC } \\
\text { at } \mathrm{pH} 7.0\end{array}$ & $\begin{array}{c}\text { Effective } \\
\text { CEC }\end{array}$ & $\begin{array}{l}\text { Aluminium } \\
\text { saturation }\end{array}$ & $\begin{array}{c}\text { Base } \\
\text { saturation }\end{array}$ & $\mathrm{Fe}$ & $\mathrm{Cu}$ & $\mathrm{Zn}$ & $\mathrm{Mn}$ & $S$ & B \\
\hline & & & \multicolumn{6}{|c|}{$\left(\mathrm{mmol}_{\mathrm{c}} \cdot \mathrm{dm}^{-3}\right)$} & & \multicolumn{3}{|c|}{$\left(\mathrm{mmol}_{\mathrm{c}} \cdot \mathrm{dm}^{-3}\right)$} & \multicolumn{2}{|c|}{ (\%) } & \multicolumn{6}{|c|}{$\left(\mathrm{mg} \cdot \mathrm{dm}^{-3}\right)$} \\
\hline $0-10$ & 4.5 & 19 & 2.1 & 15 & 10 & 5 & 66 & 0.6 & 15.6 & 28 & 94 & 33 & 15 & 30 & 60 & 1.2 & 2.0 & 8.5 & 26.5 & 0.29 \\
\hline $10-20$ & 4.2 & 16 & 1.9 & 14 & 8 & 9 & 62 & 0.7 & 14.1 & 25 & 87 & 34 & 27 & 28 & 64 & 0.8 & 1.5 & 7.8 & 35.3 & 0.29 \\
\hline $20-40$ & 4.1 & 17 & 1.2 & 14 & 8 & 10 & 59 & 0.3 & 9.6 & 24 & 83 & 34 & 30 & 29 & 54 & 0.4 & 1.0 & 5.5 & 43.9 & 0.22 \\
\hline
\end{tabular}

CEC: cation exchange capacity

(b) Granulometry (\%)

\begin{tabular}{lccccc}
$\begin{array}{l}\text { Depth } \\
(\mathrm{cm})\end{array}$ & Coarse & Medium & Fine & & \\
\hline $0-10$ & 10 & 0 & 41 & 8 & 41 \\
$10-20$ & 12 & 17 & 22 & 7 & 42 \\
$20-40$ & 12 & 10 & 26 & 6 & 46 \\
\hline
\end{tabular}

Table II.

Chemical characteristics of cattle manure used to study the effect of boron and cattle manure on fig tree productivity (Brazil).

\begin{tabular}{lccccccccccccccccc}
$\begin{array}{l}\mathrm{pH} \\
\text { (in } \mathrm{H}_{2} \mathrm{O} \text { ) }\end{array}$ & $\begin{array}{c}\text { Humidity } \\
\text { (\%) }\end{array}$ & $\mathrm{N}$ & $\mathrm{P}_{2} \mathrm{O}_{5}$ & $\mathrm{~K}_{2} \mathrm{O}$ & $\mathrm{Ca}$ & $\mathrm{Mg}$ & $\mathrm{C}$ & $\mathrm{S}$ & $\mathrm{Cl}$ & $\mathrm{Na}$ & $\mathrm{Fe}$ & $\mathrm{Cu}$ & $\mathrm{Zn}$ & $\mathrm{Mn}$ & $\mathrm{B}$ \\
\hline 8.1 & 37 & 14.2 & 8.5 & 14.6 & 7.2 & 5 & 173 & 2 & 6.25 & 0.83 & 11000 & 16 & 62 & 235 & 14.5 \\
\hline
\end{tabular}

\section{Table III.}

Leaf mean nutrient contents of fig trees determined before applying boron and cattle manure treatments in order to study the fertilization of the plants (Brazil).

\begin{tabular}{ccccccccccccc}
$\mathrm{NH}_{4}$ & $\mathrm{NO}_{3}$ & $\mathrm{P}$ & $\mathrm{K}$ & $\mathrm{Ca}$ & $\mathrm{Mg}$ & $\mathrm{S}$ & $\mathrm{Fe}$ & $\mathrm{Mn}$ & $\mathrm{Cu}$ & $\mathrm{Zn}$ & $\mathrm{B}$ \\
\hline 36.6 & 1.6 & 7.3 & 15 & 14.5 & 5.9 & 2.11 & 146 & 97 & 5.3 & 24.5 & 43.9
\end{tabular}

pests or disease, were collected [2]. The leaves were placed in paper bags and taken to the laboratory where they were ovendried at $70{ }^{\circ} \mathrm{C}$ for $48 \mathrm{~h}$ in a mechanical convection oven. When dried, the plant material was ground in a mill and subjected to analysis to determine the leaf nutrient contents. Mean leaf nutrient contents of plants (table III) were determined before applying the treatments.

A sample of five fruits was used for fruit dry matter nutrient content determinations. Fruits were dried, in a mechanical convection oven at $70{ }^{\circ} \mathrm{C}$ for $115 \mathrm{~h}$, until the fruit peel was not sticky to the touch anymore. After drying and weighing, the material was 
Table IV.

Yield, average weight and number of green figs as a function of boron and cattle manure fertilization (Brazil).

\begin{tabular}{|c|c|c|c|c|c|c|c|c|c|}
\hline \multirow[t]{2}{*}{$\begin{array}{l}\text { Boron } \\
\left(g \cdot \text { plant }^{-1}\right)\end{array}$} & \multicolumn{3}{|c|}{$\begin{array}{c}\text { Yield } \\
\left(\mathrm{kg} \cdot \mathrm{ha}^{-1}\right)\end{array}$} & \multicolumn{3}{|c|}{$\begin{array}{l}\text { Average fruit weight } \\
\text { (g) }\end{array}$} & \multicolumn{3}{|c|}{ Number of fruits per plant } \\
\hline & $\begin{array}{l}\text { With } \\
\text { manure }\end{array}$ & $\begin{array}{l}\text { Without } \\
\text { manure }\end{array}$ & Mean & $\begin{array}{l}\text { With } \\
\text { manure }\end{array}$ & $\begin{array}{l}\text { Without } \\
\text { manure }\end{array}$ & Mean & $\begin{array}{l}\text { With } \\
\text { manure }\end{array}$ & $\begin{array}{l}\text { Without } \\
\text { manure }\end{array}$ & Mean \\
\hline 0 & 7680 & 7914 & 7797 & 13.5 & 13.2 & 13.4 & 317 & 356 & 336 \\
\hline 20 & 7041 & 5957 & 6499 & 13.8 & 13.2 & 13.5 & 307 & 269 & 288 \\
\hline 40 & 8058 & 6443 & 7250 & 13.9 & 12.8 & 13.4 & 346 & 298 & 322 \\
\hline 60 & 6885 & 6573 & 6729 & 13.5 & 13.1 & 13.3 & 308 & 291 & 299 \\
\hline 100 & 7921 & 6096 & 7008 & 14.1 & 12.7 & 13.4 & 391 & 281 & 336 \\
\hline Mean & 7517 a & $6597 \mathrm{~b}$ & 7057 & $13.9 \mathrm{a}$ & $13.0 \mathrm{~b}$ & 13.4 & 334 a & $299 \mathrm{~b}$ & 316 \\
\hline Coefficient of variation of plots (\%) & & 4.1 & & & 1.79 & & & 3.06 & \\
\hline Coefficient of variation of subplot (\%) & & 15.8 & & & 4.84 & & & 14.6 & \\
\hline
\end{tabular}

ground in a mill and subjected to analysis to determine the nutrient contents. The moisture content of each sample was determined to calculate the dry matter yield and, therefore, to obtain the amount of nutrients extracted by crop yield.

Organic nitrogen $\left(\mathrm{N}_{\mathrm{Org}}=\mathrm{NH}_{4}^{+}\right), \mathrm{NO}_{3}^{-}, \mathrm{P}$, $\mathrm{K}, \mathrm{Ca}, \mathrm{Mg}, \mathrm{S}, \mathrm{Cl}, \mathrm{Fe}, \mathrm{Zn}, \mathrm{Cu}, \mathrm{Mn}$ and $\mathrm{B}$ contents were evaluated in the leaf dry matter. Analyses were carried out at the mineral nutrition laboratory in the Universidade Estadual do Norte Fluminense following the methodology described by Malavolta et al. [8], Jones et al. [9], Jackson [10] and Cawse [11].

\section{Results and discussion}

\subsection{Fruit yield}

Fruit yield, average fruit weight and number of fruits per tree were not affected by B fertilization, but they were by cattle manure levels (table IV). The yield productivity is directly related to average fruit weight and number. The highest fruit yield productivity in plots receiving cattle manure is very likely to be due to improved soil characteristics, mainly fertility, resulting from the additional nutrient supply in cattle manure [5, 6]. The average yield productivity was superior to $7000 \mathrm{~kg} \cdot \mathrm{ha}^{-1}$, varying between $(5957$ and $8058) \mathrm{kg} \cdot \mathrm{ha}^{-1}$. Hernandez et al. [12], working with the cultivar Roxo de Valinhos, whose plants were conducted with nine to twelve branches, obtained $14200 \mathrm{~kg} \cdot \mathrm{ha}^{-1}$ as maximum ripe fruit yield productivity. Nevertheless, it is important to point out that ripe fruits weigh from (50 to 60) g, whereas green figs, as evaluated herein, usually weigh, at most, $15 \mathrm{~g}$.

\subsection{Macronutrient leaf and fruit contents}

The levels of boric acid fertilization did not affect the macronutrient leaf contents. Salvador et al. [13] reported that, with an exception made for $\mathrm{P}$ and S, B levels did not affect the N, K, Ca and Mg guava tree leaf contents, but there was a linear increase in $\mathrm{P}$ and $\mathrm{S}$ contents as a function of $\mathrm{B}$ doses. According to Power and Woods [14], the positive interaction between $\mathrm{P}$ and $\mathrm{B}$ is due to the role of $\mathrm{B}$ in $\mathrm{P}$ transport across membranes.

Boric acid doses affected $\mathrm{N}_{\text {total }}\left(\mathrm{NH}_{4}^{+}+\right.$ $\mathrm{NO}_{3}^{-}$) content in fruit dry matter with significant regression curves at all sampling times, which were, respectively, $y=18.05-$ $0.0152 x$, with $R^{2}=0,50^{*}$ when no cattle 
Table V.

Fig tree leaf and fruit dry matter mean contents as a function of fertilization with cattle manure (Brazil).

(a) Macronutrient contents $\left(\mathrm{g} \cdot \mathrm{kg}^{-1}\right)$

\begin{tabular}{|c|c|c|c|c|c|c|c|c|c|c|c|c|c|c|c|c|}
\hline \multirow{2}{*}{$\begin{array}{l}\text { Cattle manure } \\
\left(\mathrm{kg} \cdot \text { plant }^{-1}\right)\end{array}$} & \multicolumn{2}{|c|}{$\mathrm{NH}_{4}^{+}$} & \multicolumn{2}{|c|}{$\mathrm{NO}_{3}^{-}$} & \multicolumn{2}{|c|}{$\mathrm{N}_{\text {total }}$} & \multicolumn{2}{|c|}{$P$} & \multicolumn{2}{|c|}{$\mathrm{K}$} & \multicolumn{2}{|c|}{$\mathrm{Ca}$} & \multicolumn{2}{|c|}{$\mathrm{Mg}$} & \multicolumn{2}{|c|}{ S } \\
\hline & Leaf & Fruit & Leaf & Fruit & Leaf & Fruit & Leaf & Fruit & Leaf & Fruit & Leaf & Fruit & Leaf & Fruit & Leaf & Fruit \\
\hline 0 & 34.6 & & 10 & 6 & . & . & 2.5 & 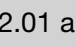 & 12. & IL & (2) & 0.0 & 585 & $25=$ & 85 & $1.14 \mathrm{a}$ \\
\hline 10 & 33.8 & 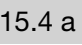 & 10 & 0. & 35 & & 2.1 & 1.9 & 15. & 12. & 12.2 & 10 & 0.4 & 2. & D & $1.15 \mathrm{a}$ \\
\hline Mean & 34.2 & 16.0 & 1.3 & 0.8 & 35.5 & 16.8 & 2.20 & 1.96 & 13.8 & 12.5 & 12.4 & 5.02 & 5.7 & 2.50 & 1.80 & 1.15 \\
\hline Coefficient of variation (\%) & 4.41 & 4.0 & 9.67 & 4.39 & 4.59 & 3.70 & 2.22 & 1.53 & 8.37 & 3.9 & 6.36 & 6.28 & 2.45 & 2.41 & 2.09 & 4.03 \\
\hline
\end{tabular}

(b) Micronutrient contents $\left(\mathrm{mg} \cdot \mathrm{kg}^{-1}\right)$

\begin{tabular}{|c|c|c|c|c|c|c|c|c|c|c|}
\hline \multirow{2}{*}{$\begin{array}{l}\text { Cattle manure } \\
\left(\mathrm{kg} \cdot \text { plant }^{-1}\right)\end{array}$} & \multicolumn{2}{|c|}{$\mathrm{Mn}$} & \multicolumn{2}{|c|}{$\mathrm{Fe}$} & \multicolumn{2}{|c|}{$\mathrm{Zn}$} & \multicolumn{2}{|c|}{ B } & \multicolumn{2}{|c|}{$\mathrm{Cu}$} \\
\hline & Leaf & Fruit & Leaf & Fruit & Leaf & Fruit & Leaf & Fruit & Leaf & Fruit \\
\hline 0 & $106.3 \mathrm{a}$ & $38.2 \mathrm{a}$ & $106.9 \mathrm{~b}$ & $43.8 \mathrm{a}$ & $23.6 \mathrm{a}$ & $22.6 \mathrm{a}$ & $81.4 \mathrm{a}$ & $31.2 \mathrm{a}$ & $6.8 \mathrm{a}$ & $5.6 \mathrm{a}$ \\
\hline 10 & $134.3 \mathrm{a}$ & $47.5 \mathrm{a}$ & $121.4 \mathrm{a}$ & $45.8 \mathrm{a}$ & $26.4 \mathrm{a}$ & $22.3 \mathrm{a}$ & $87.1 \mathrm{a}$ & $31.7 \mathrm{a}$ & $7.1 \mathrm{a}$ & $5.4 \mathrm{a}$ \\
\hline Mean & 120 & 42.8 & 114 & 44.8 & 25.0 & 22.5 & 84.2 & 31.5 & 6.9 & 5.5 \\
\hline Coefficient of variation (\%) & 19.1 & 10.0 & 4.10 & 6.0 & 14.28 & 10.70 & 13.7 & 3.30 & 6.4 & 3.8 \\
\hline
\end{tabular}

Means followed by the same letter within columns do not differ by Tukey's test at $5 \%$ probability.

manure was added and $y=15.3+0.0536 x$ - $0.0005 x^{2}$, with $R^{2}=0,74^{*}$ with cattle manure addition. The cattle manure levels did not affect either the leaf or fruit dry matter contents of $\mathrm{NH}_{4}^{+}$and $\mathrm{NO}_{3}^{-}$(table $\mathrm{V}$ ).

There was no effect of boric acid levels on $\mathrm{P}$ contents in fruit dry matter. On the other hand, cattle manure levels affected $\mathrm{P}$ contents both in leaves and fruit, with a marked increase when no cattle manure was applied (table $V$ ). Despite the significant effects of fertilization with cattle manure, the means presented little variation, around 5\%.

There was a significant interaction between boric acid and cattle manure on $\mathrm{K}$ contents in fig fruit dry matter: boric acid effects on $\mathrm{K}$ contents were only observed when $10 \mathrm{~g}$ of cattle manure per plant were applied $\left(y=-0.00052 x^{2}+0.0644 x+11.5\right.$ $\left.R^{2}=0,99^{*}\right)$. According to Power and Woods [14], K uptake increases with B availability, being almost nonexistent in its absence. The leaf and fruit dry matter $\mathrm{K}$ contents were not affected by cattle manure (table $\mathrm{V}$ ).

The leaf macronutrient contents observed, with an exception made for $\mathrm{Ca}$ and $\mathrm{Mg}$, are within the range considered adequate by Quaggio et al. [2]. According to these authors, the normal contents should be 30 $50 \mathrm{~g} \cdot \mathrm{kg}^{-1}$ for $\mathrm{Ca}$, and $7.5-10 \mathrm{~g} \cdot \mathrm{kg}^{-1}$ for $\mathrm{Mg}$ Nevertheless, the $\mathrm{Ca}$ and $\mathrm{Mg}$ contents that we found are close to the ranges presented by Pereira [1], which were $13-16 \mathrm{~g} \cdot \mathrm{kg}^{-1}$ for $\mathrm{Ca}$ and $3.2-4.2 \mathrm{~g} \cdot \mathrm{kg}^{-1}$ for $\mathrm{Mg}$. It must be pointed out that, besides the fact of no deficiency symptoms of any nutrient being observed, the average obtained for the yield productivity value (table IV) can be considered as high. Quaggio et al. [2] and Pereira [1] did not report either the yield productivity values or the crop management practices for the fig plants in which the reported nutrient contents were observed.

\subsection{Micronutrient leaf and fruit contents}

As a response to boric acid levels, increased Mn contents were observed in the fruit $\left(y=0.103 x+38.4, R^{2}=0.65^{*}\right)$ and leaf $\left(y=0.397 x+103, R^{2}=0.73^{*}\right)$ dry matter when $\mathrm{B}$ was added to the soil, regardless of 
sampling time and manure addition. Nakayama [15] observed otherwise when studying young cacao plants; that is, the Mn leaf contents decreased in response to boric acid addition to the soil. The cattle manure levels did not affect the Mn contents in either fruit or leaves (table $V$ ). The Fe leaf contents were significantly higher under manure application, whereas in fruit there was no manure effect (table $V$ ).

A linear response to boric acid levels was observed in Zn contents $(y=0.0688 x+$ 21.9, $\left.R^{2}=0.88^{*}\right)$. Lima Filho [16] studied the interaction between $\mathrm{B}$ and $\mathrm{Zn}$ in coffee plants and he observed that the increase in both coffee plant dry matter yield and B leaf contents, as a function of $\mathrm{B}$ added to the soil, only took place when increasing $\mathrm{Zn}$ levels, and vice versa. Nakayama [15], varying B levels from (0 to 0.50$) \mathrm{mg} \cdot \mathrm{kg}^{-1}$ of soil, found a proportional increase in $\mathrm{Zn}$ leaf contents (32-51 $\mathrm{mg} \cdot \mathrm{kg}^{-1}$ ) in young cacao plants grown in pots. Both $\mathrm{B}$ and $\mathrm{Zn}$ are essential to ATPase and plasma membrane redox systems functioning well; that is, without $\mathrm{B}$ and $\mathrm{Zn}$, their efficiency can be reduced, and vice versa [14].

The B contents, both in leaf and fruit dry matter, were increased according to boric acid levels $\left(y=0.731 x+52.1, R^{2}=0.99^{* * *}\right.$ for leaf dry matter; $y=0.0749 x+28.2, R^{2}=$ $0.90 *$ for fruit) but did not respond to cattle manure fertilization (table $\mathrm{V}$ ). Salvador et al. [13] observed a linear increase in B guava leaf contents as a function of fertilization with B. According to Brown and $\mathrm{Hu}$ [17], B uptake is proportional to its concentration in the soil solution.

The $\mathrm{B}$ mean leaf contents (above $80 \mathrm{mg} \cdot \mathrm{kg}^{-1}$ ) were higher than those considered adequate by Quaggio et al. [2], i.e., 30$75 \mathrm{mg} \cdot \mathrm{kg}^{-1}$, which is an expected result due to the nature of the experiment: $41.7 \mathrm{mg} \cdot \mathrm{kg}^{-1}$ observed in plots without boric acid, and values above $100 \mathrm{mg} \cdot \mathrm{kg}^{-1}$ at the highest boron level. Despite the supply of up to $100 \mathrm{~g}$ boric acid per plant $\left(16 \mathrm{~kg} \cdot \mathrm{ha}^{-1}\right), \mathrm{B}$ leaf contents were not increased to cause toxicity symptoms, which might have happened, as reported in the literature [3, 15, 18], as the line between deficiency and toxicity of this nutrient is very subtle. Nevertheless, it must be taken into account that
$B$ availability is affected by nutrient leaching and adsorption to soil particles [19].

Boric acid affected $\mathrm{Cu}$ contents only in fruit dry matter $(y=5.5+0.0123 x-$ $\left.0.0002 x^{2}, R^{2}=0.62^{*}\right)$. Salvador et al. [13] did not find any effect of fertilization with $\mathrm{B}$ on $\mathrm{Cu}, \mathrm{Fe}, \mathrm{Mn}$ or $\mathrm{Zn}$ leaf contents. The micronutrient contents are within the range considered adequate by Quaggio et al. [2], except $\mathrm{Zn}$ contents, which are considered low. On the other hand, Pereira [1] reports $\mathrm{Zn}$ contents between (15 and 30) $\mathrm{mg} \cdot \mathrm{kg}^{-1}$ as adequate; thus, the values reported herein are considered to be sufficient according to this author.

\subsection{Amounts of nutrients extracted per hectare per crop yield}

The levels of cattle manure did not significantly affect the amount of nutrients extracted by green fig crop yield. The average crop yields were (7517 and 6597) $\mathrm{kg} \cdot \mathrm{ha}^{-1}$, respectively, with and without cattle manure addition (table IV).

Regression analyses show significant results only for the extracted amounts of $\mathrm{Mn}$ $\left(y=0.087 x+29.9, R^{2}=0.57^{*}\right)$ and $\mathrm{B}(y=$ $\left.0.0842 x+28.6, R^{2}=0.56^{*}\right)$, whose values increased with the increase in boric acid levels. These results are similar to the ones observed for leaf and fruit contents. The interaction between $\mathrm{B}$ and cattle manure levels was not significant when nutrient extraction values were considered.

The macronutrient extraction order was $\mathrm{N}>\mathrm{K}>\mathrm{Ca}>\mathrm{Mg}>\mathrm{P}>\mathrm{S}$, with the following mean amounts extracted: (N, 17.2; K, 13.3; Ca, $4.56 \mathrm{~kg}$; Mg, 2.07; P, 2.03; S, $0.90) \mathrm{kg} \cdot \mathrm{ha}^{-1}$ per crop yield (table VI). The micronutrient extraction order was $\mathrm{Fe}>$ $\mathrm{Mn}>\mathrm{B}>\mathrm{Zn}>\mathrm{Cu}($ table $V I)$.

Hernandez et al. [20] reported that, for a fruit yield of $10 \mathrm{t} \cdot \mathrm{ha}^{-1}$ of ripe figs and $1.3 \mathrm{ha}^{-1}$ of green figs, Roxo de Valinhos fig trees exported $32.0 \mathrm{~kg} \cdot \mathrm{ha}^{-1}$ of $\mathrm{N}$, $1.5 \mathrm{~kg} \cdot \mathrm{ha}^{-1}$ of $\mathrm{P}, \quad 31.4 \mathrm{~kg} \cdot \mathrm{ha}^{-1}$ of $\mathrm{K}$, $9.0 \mathrm{~kg} \cdot \mathrm{ha}^{-1}$ of $\mathrm{Ca}$ and $3.5 \mathrm{~kg} \cdot \mathrm{ha}^{-1}$ of $\mathrm{Mg}$. Hiroce et al. [21] estimated that, to attain a yield of $22 \mathrm{t} \cdot \mathrm{ha}^{-1}$ of ripe figs, the plant should export $69.1 \mathrm{~kg}$ of $\mathrm{N}, 10.4 \mathrm{~kg}$ of $\mathrm{P}$, $87.2 \mathrm{~kg}$ of $\mathrm{K}, 24.1 \mathrm{~kg}$ of $\mathrm{Ca}, 6.71 \mathrm{~kg}$ of $\mathrm{Mg}$, 
Table VI.

Nutrient extraction estimates by fig tree fruit yield as a function of fertilization with cattle manure (Brazil).

(a) Macronutrient extraction estimates $\left(\mathrm{kg} \cdot \mathrm{ha}^{-1}\right.$ per crop yield)

\begin{tabular}{lccccccccc}
$\begin{array}{l}\text { Cattle manure } \\
\left(\mathrm{kg} \cdot \text { plant }^{-1} \text { ) }\right.\end{array}$ & $\mathrm{NH}_{4}^{+}$ & $\mathrm{NO}_{3}^{-}$ & Ntotal & $\mathrm{P}$ & $\mathrm{K}$ & $\mathrm{S}$ & $\mathrm{Ca}$ & $\mathrm{Mg}$ \\
\hline 0 & $16.1 \mathrm{a}$ & $0.7 \mathrm{a}$ & $16.9 \mathrm{a}$ & $2.0 \mathrm{a}$ & $12.3 \mathrm{a}$ & $0.8 \mathrm{a}$ & $4.2 \mathrm{a}$ & $1.9 \mathrm{a}$ \\
10 & $16.7 \mathrm{a}$ & $0.9 \mathrm{a}$ & $17.6 \mathrm{a}$ & $2.1 \mathrm{a}$ & $14.3 \mathrm{a}$ & $0.9 \mathrm{a}$ & $4.9 \mathrm{a}$ & $2.2 \mathrm{a}$ \\
\hline Mean & 16.4 & 0.8 & 17.2 & 2.0 & 13.3 & 0.8 & 4.5 & 2.0 \\
Coefficient of variation (\%) & 8.1 & 7.1 & 8.0 & 6.8 & 8.0 & 6.6 & 9.8 & 6.3
\end{tabular}

(b) Micronutrient extraction estimates $\left(\mathrm{g} \cdot \mathrm{ha}^{-1}\right.$ per crop yield)

\begin{tabular}{lccccc}
$\begin{array}{l}\text { Cattle manure } \\
\left(\mathrm{kg} \cdot \text { plant }^{-1} \text { ) }\right.\end{array}$ & $\mathrm{Mn}$ & $\mathrm{Fe}$ & $\mathrm{Zn}$ & $\mathrm{B}$ & $\mathrm{Cu}$ \\
\hline 0 & $29.9 \mathrm{a}$ & $44.7 \mathrm{a}$ & $22.3 \mathrm{a}$ & $30.2 \mathrm{a}$ & $7.6 \mathrm{a}$ \\
10 & $37.5 \mathrm{a}$ & $51.3 \mathrm{a}$ & $23.2 \mathrm{a}$ & $34.4 \mathrm{a}$ & $8.2 \mathrm{a}$ \\
\hline Mean & 33.7 & 48.0 & 22.8 & 32.3 & 7.9 \\
Coefficient of variation (\%) & 22.5 & 9.2 & 11.4 & 6.2 & 9.3 \\
\hline
\end{tabular}

Means followed by the same letter within columns do not differ by Tukey's test at $5 \%$ probability.

$6.37 \mathrm{~kg}$ of S, $154 \mathrm{~g}$ of $\mathrm{B}, 3 \mathrm{~kg}$ of $\mathrm{Cl}, 339 \mathrm{~g}$ of $\mathrm{Cu}, 168 \mathrm{~g}$ of $\mathrm{Fe}, 67 \mathrm{~g}$ of $\mathrm{Mn}, 1.34 \mathrm{~g}$ of Mo and $58 \mathrm{~g}$ of $\mathrm{Zn}$. Nevertheless, the exclusive yield of green fig shows differentiated nutrient demand, making comparisons difficult.

\subsection{Fig tree leaf and fruit dry matter nutrient contents as a function of sampling dates}

The fig tree leaf nutrient contents vary with the plant physiological stages during its production cycle. All nutrient contents, except $\mathrm{Mn}, \mathrm{S}$ and $\mathrm{Mg}$, increased at the second sampling date (3 October 2004) as compared with the first one's (27 January 2004) results (table VII). Proebsting and Warner [22], studying Adriatic and Calimyrna fig varieties, evaluated the N, P, K, Ca and Mg leaf contents between April and September; they observed that the $\mathrm{N}$ and $\mathrm{P}$ contents decreased with plant development; the $\mathrm{K}$ contents showed an unusual tendency, that is, there was a great increase in leaf content between April and June, decreasing thereafter until September; the Ca and Mg contents increased during the period April to September.

\section{Conclusions}

In our experiments, fig tree yield productivity $\left(7517 \mathrm{~kg} \cdot \mathrm{ha}^{-1}\right)$ was superior under treatments with cattle manure addition, and fertilization with boric acid did not affect the fig tree yield productivity. The Mn, $\mathrm{Zn}$ and $\mathrm{B}$ leaf contents and the fruit extraction of $\mathrm{Mn}$ and $\mathrm{B}$ increased linearly with boric acid levels. The leaf nutrient content in the fig tree varied with the leaf sampling date. All these results should be taken into account for the development of the next fig tree fertilization programs in Brazil.

\section{References}

[1] Pereira F.M, Cultura da figueira, Livro Ceres, Piracicaba, Brazil, 1981.

[2] Quaggio J.A., Raij B.V, Piza C.T. Jr., Frutíferas: amostragem de folhas e diagnose foliar, In: Raij B.V., Cantarella H., Quaggio J.A., Furlani A.M.C. (Eds.), Recomendações de adubação e calagem para o Estado de São Paulo, Bol. Téc., 100, Inst. Agron., Campinas, Brazil, 1996.

[3] Quaggio J.A., Piza C.T. Jr., Frutíferas tropicais, In: Ferreira M.E., Cruz M.C.P., Raij B.V., 
Table VII.

Fig tree leaf and fruit dry matter contents as a function of sampling dates (Brazil).

(a) Mean macronutrient contents $\left(\mathrm{g} \cdot \mathrm{kg}^{-1}\right)$

\begin{tabular}{|c|c|c|c|c|c|c|c|c|c|c|c|c|c|c|c|c|}
\hline \multirow{2}{*}{$\begin{array}{l}\text { Date of sampling } \\
(2004)\end{array}$} & \multicolumn{2}{|c|}{$\mathrm{NH}_{4}^{+}$} & \multicolumn{2}{|c|}{$\mathrm{NO}_{3}^{-}$} & \multicolumn{2}{|c|}{$\mathrm{N}_{\text {total }}$} & \multicolumn{2}{|c|}{$P$} & \multicolumn{2}{|c|}{$\mathrm{K}$} & \multicolumn{2}{|c|}{$\mathrm{Ca}$} & \multicolumn{2}{|c|}{$\mathrm{Mg}$} & \multicolumn{2}{|c|}{$\mathrm{S}$} \\
\hline & Leaf & Fruit & Leaf & Fruit & Leaf & Fruit & Leaf & Fruit & Leaf & Fruit & Leaf & Fruit & Leaf & Fruit & Leaf & Fruit \\
\hline t vallu & $4.0 \mathrm{a}$ & 1 & 1 & 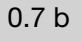 & 3 & 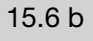 & 2 & 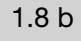 & 1. & $11.2 \mathrm{~N}$ & N & $5.3 \mathrm{a}$ & $6.1 \mathrm{a}$ & $2.8 \mathrm{a}$ & $1.8 \mathrm{a}$ & $1.3 \mathrm{a}$ \\
\hline 10 March & $34.4 \mathrm{a}$ & $17.2 \mathrm{a}$ & 1 & $.8 \mathrm{a}$ & $35.9 \mathrm{a}$ & $18.0 \mathrm{a}$ & $2.2 \mathrm{a}$ & $2.1 \mathrm{a}$ & $14.4 \mathrm{a}$ & 13.9 & $12.6 \mathrm{a}$ & $4.7 \mathrm{~b}$ & $5.3 \mathrm{~b}$ & $2.1 \mathrm{~b}$ & $1.7 \mathrm{a}$ & $0.9 b$ \\
\hline Cant & 4.2 & 10 & 1.0 & 0.0 & 35.5 & 16.8 & 2.18 & 1.97 & 13.8 & 12.25 & 12.37 & 5.02 & 5.71 & 2.50 & 1.80 & 1.15 \\
\hline Coefficient of variation (\%) & 9.91 & 10.9 & 13.2 & 15.0 & 9.74 & 10.68 & 7.92 & 9.83 & 8.92 & 9.82 & 9.79 & 11.07 & 9.02 & 10.23 & 15.30 & 12.63 \\
\hline
\end{tabular}

(b) Mean micronutrient contents $\left(\mathrm{mg} \cdot \mathrm{kg}^{-1}\right)$

\begin{tabular}{|c|c|c|c|c|c|c|c|c|c|c|}
\hline \multirow{2}{*}{$\begin{array}{l}\text { Date of sampling } \\
\text { (2004) }\end{array}$} & \multicolumn{2}{|c|}{$\mathrm{Mn}$} & \multicolumn{2}{|c|}{$\mathrm{Fe}$} & \multicolumn{2}{|c|}{$\mathrm{Zn}$} & \multicolumn{2}{|c|}{$\mathrm{Mn}$} & \multicolumn{2}{|c|}{$\mathrm{Mn}$} \\
\hline & Leaf & Fruit & Leaf & Fruit & Leaf & Fruit & Leaf & Fruit & Leaf & Fruit \\
\hline 27 January & $143.2 \mathrm{a}$ & $50.7 \mathrm{a}$ & $116.2 \mathrm{a}$ & $39.9 \mathrm{~b}$ & $25.9 \mathrm{a}$ & $21.3 b$ & $78.8 \mathrm{~b}$ & $29.3 b$ & $6.5 \mathrm{~b}$ & $2.7 \mathrm{~b}$ \\
\hline 10 March & $97.5 \mathrm{~b}$ & $35.1 \mathrm{~b}$ & $112.1 \mathrm{a}$ & $49.7 \mathrm{a}$ & $24.1 \mathrm{a}$ & $23.6 \mathrm{a}$ & $89.7 \mathrm{a}$ & $33.6 \mathrm{a}$ & $7.4 \mathrm{a}$ & $8.3 \mathrm{a}$ \\
\hline Mean & 120.3 & 42.8 & 114.1 & 44.8 & 25.0 & 22.4 & 84.2 & 31.4 & 6.9 & 5.5 \\
\hline Coefficient of variation (\%) & 26.59 & 15.30 & 8.77 & 16.50 & 24.96 & 10.0 & 22.01 & 10.7 & 14.74 & 17.0 \\
\hline
\end{tabular}

Means followed by the same letter within columns do not differ by Tukey's test at $5 \%$ probability.

Abreu C.A. (Eds.), Micronutrientes e elementos tóxicos na agricultura, CNPq/FAPESP/ POTAFOS, Jaboticabal, Brazil, 2001.

[4] Campo-Dall'Orto F.A., Barbosa W., Quaggio B.V., Frutíferas: frutas de clima temperado, II, In: Raij B.V., Cantarella H., Quaggio J.A., Furlani A.M.C. (Eds.), Recomendações de adubação e calagem para o Estado de São Paulo, Bol. Téc., 100, Inst. Agron., Campinas, Brazil, 1996.

[5] Franchini J.C., Malavolta E., Miyazawa M., Pavan M.A., Alterações químicas em solos ácidos após a aplicação de resíduos vegetais, Rev. Bras. Ciênc. Solo 23 (1999) 533542.

[6] Mello S.C., Vitti G.C, Influência de materiais orgânicos no desenvolvimento do tomateiro e nas características químicas do solo em ambiente protegido, Hortic. Bras., Brasília, 20 (2002) 452-458.

[7] Cakmak I., Römheld V., Boron deficiencyinduced impairments of cellular functions in plants, Plant Soil 193 (1997) 121-123.

[8] Malavolta E., Vitti G.C., Oliveira, S.A., Avaliação do estado nutricional das plantas: princípios e aplicações, POTAFOS, Piracicaba, Brazil, 1989.
[9] Jones J.B. Jr., Wolf B., Mills H.A, Plant analysis handbook: a practical sampling, preparation, analysis, and interpretation guide, Micro-Macro Publ., Athens, USA, 1991.

[10] Jackson M.L., Soil chemical analysis, Prentice Hall, New Jersey, USA, 1958.

[11] Cawse P.A., The determination of nitrate in soil solution by ultraviolet spectrophotometry, Anal. 9 (1967) 309-313.

[12] Hernandes F.B.T., Suzuki M.A., Frizzone J.A., Tarsitano M.A.A., Pereira G.T., Correa L.S., Função de produção da figueira à aplicação de doses de nitrogênio e lâminas de água, Eng. Agríc. 16 (1996) 22-30.

[13] Salvador J.O., Moreira A., Malavolta E., Cabral C.P., Influência do boro e do manganês no crescimento e na composição mineral de mudas de goiabeira, Ciênc. Agrotec. 27 (2003) 325-331.

[14] Power P.P., Woods W.G., The chemistry of boron and its speciation in plants, Plant Soil 193 (1997) 1-13.

[15] Nakayama L.H.I., Influência de doses de boro e zinco no desenvolvimento e nutrição mineral do cacaueiro, Agrotróp. 1 (1989) 34-38. 
[16] Lima Filho O.F., Malavolta E., Evaluation of extraction procedures on determination of critical soil and foliar levels of boron and zinc in coffee plants, Commun. Soil Sci. Plant Anal. 29 (1998) 825-833.

[17] Brown P.H., Hu H., Phloem boron mobility in diverse plant species, Bot. Actae 337 (1998) 331-335.

[18] Noble M.E., Blevins D.G., Miles R.J., Extra boron maintains root growth under toxic aluminum conditions, Better Crop. Plant Food 77 (1993) 3-5.

[19] Goldberg, S., Reactions of boron with soils, Plant soil 193 (1997) 35-48.
[20] Hernandes F.B.T., Modesto J.C., Suzuki M.A., Correa L.S., Effects of irrigation and nitrogen levels on qualitative and nutritional aspects of fig-trees (Ficus carica L.), Sci. Agric. 51 (1994) 292-298.

[21] Hiroce R., Ojima M., Gallo J.R., Bataglia O.C., Furlani P.R., Composição mineral e exportação de nutrientes pelas colheitas de frutos subtropicais e temperados, An. Congr. Bras. Frutic. 5 (1979) 179-189.

[22] Proebsting E.L., Warner R.M., The effect of fertilizers on yield, quality and leaf composition of figs, Proc. Am. Soc. Hortic. Sci. 63 (1984) 10-18.

\section{Resultados preliminares sobre la productividad y la composición mineral de} la higuera en función de la fertilización en boro y en estiércol de bovino en Brasil.

Resumen - Introducción. Las informaciones sobre la relación entre el contenido en elementos nutritivos de las hojas y la productividad de la higuera aún faltan en Brasil. El objetivo de nuestras investigaciones fue evaluar el efecto de la fertilización con boro y con estiércol de bovinos sobre la productividad de la higuera, el contenido en elementos nutritivos de las hojas y estimar la exportación de los elementos minerales en los frutos cosechados. Material y métodos. Los tratamientos se constituyeron de cinco niveles de ácido bórico $[(0,20,40,60$ y 100) g por planta] combinados con dos dosis de estiércol de bovino $[(0,10) \mathrm{kg}$ por planta]. El dispositivo experimental fue el de bloques aleatorios de acuerdo con un modelo de split-plot de cuatro replicaciones. Las dosis de estiércol constituyeron los tratamientos y los niveles de boro los sub-tratamientos. Estudiamos la productividad de los árboles en fruto, el contenido de las hojas y de los frutos en macro y en micro-elementos, la cantidad de elementos minerales extraída por ha y por cosecha, el contenido mineral de la materia seca de las hojas y de los frutos en función de las fechas de extracción. Resultados. La fertilización de boro no afectó la productividad, ni el peso medio de los frutos, ni el número de frutos por árbol; pero, estos parámetros variaron con las dosis de estiércol, las cuales mejoraron el rendimiento de la higuera. Se discute el contenido de las hojas y de los frutos en macro- y en micro-elementos en relación con los resultados obtenidos en Brasil ya publicados. Las dosis de estiércol no afectaron significativamente la cantidad de elementos extraídos a partir de la cosecha de higos verdes. Los contenidos de las hojas en Mn, Zn y B así como la extracción por el fruto del Mn y del B aumentaron linealmente junto con los distintos niveles de ácido bórico. El contenido en elementos minerales de las hojas de higuera varió junto con el estado fisiológico de la planta en curso de su ciclo de producción. Conclusión. Será importante tener en cuenta estos resultados para el desarrollo de los futuros programas de fertilización de la higuera en Brasil.

Brasil / Ficus carica / aplicación de abonos / boro / estiércol / contenido mineral / hojas / frutas / aumento del rendimiento 